\title{
APPLICATION OF G8D METHOD FOR THE QUALITY ISSUE ANALYSIS IN A MANUFACTURING COMPANY
}

\author{
Anna CHOMICZ \\ Warsaw University of Technology, Warsaw, Faculty of Management, Poland; anna.chomicz.dokt@pw.edu.pl, \\ ORCID: 0000-0003-4912-3303
}

Purpose: The article reviews the literature on the concept of Global 8 Disciplines method in the context of root cause analysis of the quality issue.

Design/methodology/approach: In this paper the objective was set to prevent quality issues regarding the surface of wire rod coils. In order to achieve this, the G8D problem solving method was applied to analyze and solve the problem.

Findings: G8D does improve the efficiency of quality issue problem-solving.

Originality/value: G8D method application allows reducing problem analysis time and costs in the manufacturing companies.

Keywords: Global 8 Disciplines, quality issue, quality improvement.

Category of the paper: Empirical research.

\section{Introduction}

Continuous improvement is a key factor to be maintained in companies that have implemented the PN-EN ISO 9001:2015 quality system. Now, ISO 9001:2015 strives to give additional momentum to the continuous and systematic improvement of processes within organization. Process effectiveness enhancement in the whole system within the entire organization is crucial. Internal audits and reviews actions handled by leadership are therefore required to improve tasks and processes of the quality system (PN-EN ISO 9000:2015). A method that may help to maintain continuous improvement actions within the organization is that of Global 8 Disciplines (widely known as an abbreviation - G8D or TOPS 8D). The G8D method is one of the most widely used problem-solving tools applied for the prevention of repeated nonconformities in the manufacturing process. Additionally, it is used for complaint management (Xu and Dang and Munro, 2018). 
The aforementioned method was first established in Ford Motor Company for use by its suppliers to improve problem-solving. Subsequently, at the beginning of the eighth decade of the XX century, the method was transformed into Team Oriented Problem Solving Eight Disciplines (TOPS 8D). The G8D utilization developed powerful strategies for archiving problem-solving efforts (Rambaud, 2006). G8D is broadly used especially in automotive industries for service issues, including that of supplier qualification confirmation, maintenance, process deviations, customer complaints or purchases (Chen and Cheng, 2010). Application of the G8D method is useful for indicating the actions to take to solve the problem temporarily and then the actions to enable permanent correction. By this means G8D application solves the issue thoroughly especially when it involves the coordination of various departments (sometimes even third parties, such as suppliers, clients and logistics companies) in order to resolve issues. In the presented case, the G8D method was put forward to solve the quality issues of wire rod coils. The main area of this paper is the process of quality improvement.

\section{Literature Review}

The research question for this investigation is: How to prevent quality issues of wire rod manufacture and ward off repetition? Many authors describe the eight disciplines as a form of systematic problem solving. Global Eight Disciplines (G8D) Problem Solving is a method that uses a step-by-step approach for deriving solutions. This includes identifying, correcting, and eliminating recurring problems. The G8D is a management approach that has been adopted in the automotive industry processes but can be applied also in other areas such as logistics, warehousing or aftersales (Ramachandran, 2013). Global Eight Disciplines need supporting tools and techniques in order to complete the tasks in each step (Table 1). The G8D approach is utilized to identify issues, find weaknesses in the system and prevent them from repeating (Łuczak, and Matuszak-Flejszman, 2007). The G8D method requires the cooperation of groups of particular area experts. By way of their knowledge and experience, team members are able to identify the root cause of the issue and to suggest potential resolution. The group of experts is required to have in mind the good interest of the company - to do so, they ought to take into consideration not only technical aspects, but also economic perspectives (Banduka, and Tadic, and Macuzic, 2018).

As depicted in the Table 1, the G8D consists of eight Disciplines. 
Table 1.

Supporting tools and techniques in order to complete the tasks in each the G8D Discipline

\begin{tabular}{|c|c|c|}
\hline $\begin{array}{l}\text { Discipline } \\
\text { number }\end{array}$ & Name of the G8D* Discipline & $\begin{array}{l}\text { Examples of tools and techniques supporting } \\
\text { execution of each Discipline }\end{array}$ \\
\hline D1 & Establishment of the team & relationship diagram, previous G8D reports \\
\hline D2 & Problem definition & $\begin{array}{l}\text { previous G8D reports, brainstorming, Pareto diagram, } \\
\text { Ishikawa diagram, ABCD method, data collection for } \\
\text { background information }\end{array}$ \\
\hline D3 & $\begin{array}{l}\text { Identification of the temporary } \\
\text { corrective actions }\end{array}$ & $\begin{array}{l}\text { Gantt chart, FMEA analysis, risk analysis, previous } \\
\text { G8D reports }\end{array}$ \\
\hline D4 & Identification of potential causes & $\begin{array}{l}\text { Gantt chart, FMEA analysis, risk analysis, previous } \\
\text { G8D reports, Ishikawa diagram, cause and effect } \\
\text { diagram }\end{array}$ \\
\hline D5 & Indication of corrective actions & $\begin{array}{l}\text { ABCD method, histograms, Statistical Process Control, } \\
\text { Process } \\
\text { Capability, Process Capability index, Pareto diagram, } \\
\text { previous G8D reports }\end{array}$ \\
\hline D6 & $\begin{array}{l}\text { Implementation of corrective actions - } \\
\text { Measuring of effectiveness }\end{array}$ & PDCA chart, Gantt chart, previous G8D reports \\
\hline D7 & $\begin{array}{l}\text { Implementation of corrective and } \\
\text { preventive measures and validation }\end{array}$ & $\begin{array}{l}\text { Previous G8D reports, FMEA analysis, Pareto } \\
\text { diagram, SPC data }\end{array}$ \\
\hline$D 8$ & Summation report & Previous G8D reports \\
\hline
\end{tabular}

* G8D stands for Global 8 Disciplines

Adapted from: own study based on Babica, and Pająk, 2006, Łuczak, and Maćkiewicz, 2006, Pacana, and Czerwińska, 2017.

The Team members are able to find issue resolution by following step-by-step the entire G8D path, using the aforementioned tools and techniques.

The $D 1$ stage allows identifying the defect, which can be related to a product or service. Herein, the key information on the issue is entered, for example, G8D serial number, date, identification number, name, reference to plan, number of quantity, selection of particular team members with high level of expertise and competences (Luczak, and Maćkiewicz, 2006).

$D 2$ is when the issue is defined. During this stage, team members attempt to acquire more information from the client, vendor, transporter or other third parties connected with the identified problem. The mentioned task constitutes the first analysis performed in the problemsolving process. The nature of issue has to be given, along its effects. Other necessary information includes knowing if the problem is intermittent and if it has shown up in similar products or processes. In discerning the problem, the 5 Why? analysis (why, who, what, where, when) and 2 How? (how, much or many) methods are applied so as to clarify the background and to discover possible connectivity (Kumar, and Adaveesh, 2017).

During the $D 3$ stage, the problem has to be identified and temporary corrective actions have to be implemented. In $D 3$, incorrect action or process of manufacturing of product with failures has to be stopped as soon as possible. In the car industry, the typical time frame taken for such action is roughly 24 hours (Sarkar and Rajagopalan, 2018).

In $D 4$, by applying, for instance, Ishikawa diagrams, brainstorming or cause and effect diagrams (Table 1), the potential root of the problem can be revealed. 
During the D5 phase, the Team members have to ascertain if the customer complaint necessitates changes in the FMEA (Failure Mode and Effects Analysis), in control documentation or other related records. If the change has been identified, it is crucial to incorporate it in the above-noted reports (Banduka, and Tadic, and Macuzic, 2018).

In D6, long-term effectiveness of the previous step is measured and corrective actions are enacted. The default time in the automotive industries for this measurement being implemented has been set to 90 days, however, the time period can be aligned to comply to client requirements (Sarkar, and Rajagopalan, 2018). If the process capability meets the requirements, the client/supplier verifies the applied corrective measure.

Within $D 7$, team members have to validate if the permanent corrective actions were correctly executed and implemented. Additionally, the team has to analyze the possibility of change and to establish an analysis of the entire process. As part of the D7 Discipline, it is recommended to:

- assess the state after the permanent corrective actions are implemented,

- choose the best preventive actions,

- enact preventive actions,

Preventive actions must be archived in the summation G8D report (Łuczak. and MatuszakFlejszman, 2007).

During the $D 8$ stage, the team of experts prepare the summation report. In the mentioned report, the team's achievements and the results of the activities and lessons learned must be listed. The final element of the team-work is to express the appreciation of their efforts (Kumar, and Adaveesh, 2017).

\section{Analysis and improvement using the G8D method}

Quality issue was detected in the manufacturer plant, during the manufacture of carpentry nails. The manufacturer processes the nails from wire rod. The wire rod is fed into a nail making machine, which produces roughly 650 nails per minute. The nails, are subsequently, formed, cleaned, finished and packaged.

Quality control revealed that dozens of nails had defects. The problem required G8D application because it concerned all parties (producer, transporter and client), but emergency response action was not needed. During the Dl stage, the team was selected (five individuals). The team consisted of product manager, the quality manager from the wire rod producer side and the key account manager from the transportation company, as well as the commodity manager and quality manager from the client side. The team members were then made familiar with each other, the process, product and problem so as to quickly implement 
appropriate corrective actions - in this case, before the next delivery of wire rod. The agreedupon team objectives were to identify the root causes of the wire rod quality issue and to mitigate the problem.

Entering into $2 A$, the G8D Team was provided with an accurate description of the issue, and all terms applied were made understandable by all team members. Herein, all team members were made aware that the nails manufacturer received a product from the wire rod provider. After a few days, the nail manufacturer announced problems with the processing of this wire rod. The problem consisted of deep abrasions on the surface of some windings on several coils. The issue had a huge impact on the nails manufacturer production efficiency as the wire rod broke during processing.

During the session (within D2 discipline), the team agreed that more detailed information related to the problematic coils was required. This included the number of affected coils, the batch numbers and date of delivery, photos of the transported product, labels, description of uploading/unloading process, photos of delivery to processing place, description of processing mode (examples on Figure 1 and Figure 2).

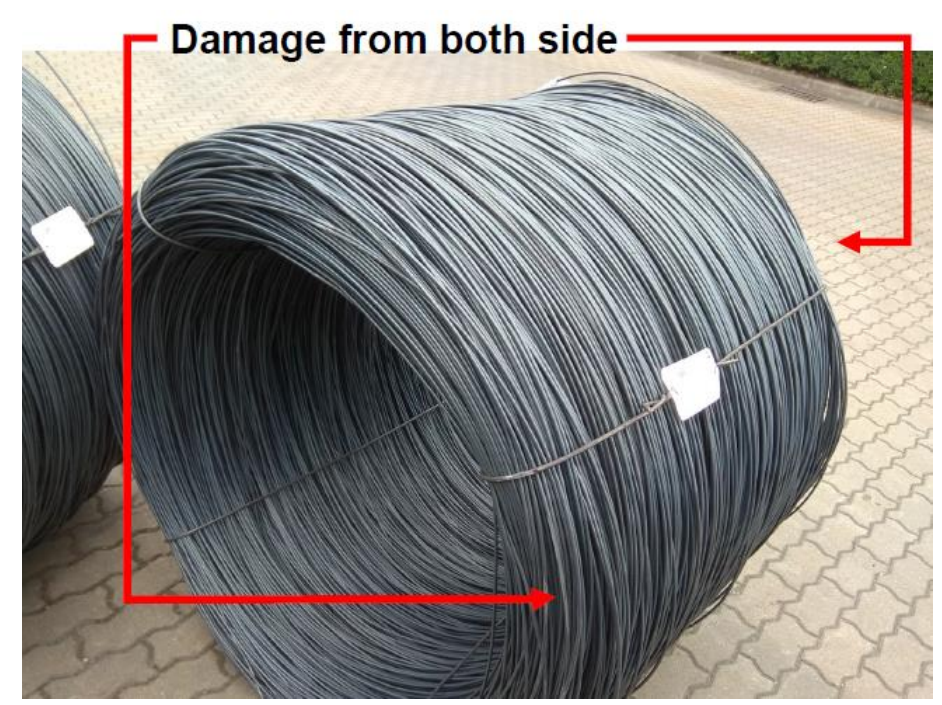

Figure 1. Unloaded wire rod with damage on both sides. Adapted from: Company materials.

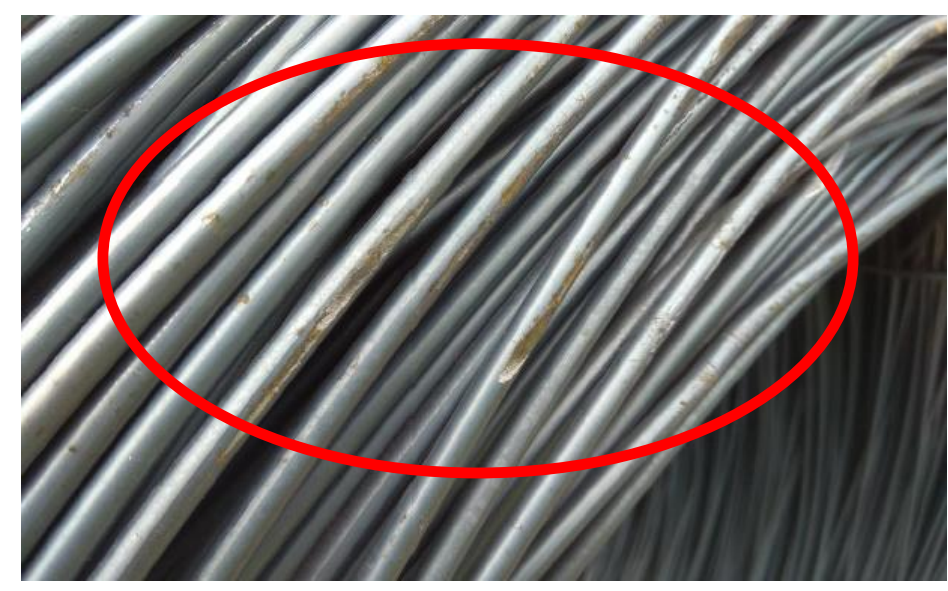

Figure 2. Quality issues that affected the manufacturing process. Adapted from: Company materials. 
The G8D Team decided additionally that the wire rod manufacturer should analyze all necessary data and present their standpoint as to how to eliminate the issue in the future. This ended the first session.

During the next meeting, still within the $2 D$ phase, the G8D discussion was about potential root causes of the failed coils and issues with the material. During the brainstorming session, more information was uncovered using 5 Why? and 2How? analysis (why, who, what, where, when) and 2 How? analysis (how, much or many), with the previously requested information being mined for answers (Table 2).

Table 2.

Application of 5 Why? and 2 How? to analyze the root cause

\begin{tabular}{|c|c|c|}
\hline $2 D$ & IS & IS NOT \\
\hline$\ddot{\dot{\theta}}$ & $\begin{array}{l}\text { Who is affected by the problem? } \\
\text { Nail producer, wire rod provider, transporter } \\
\text { Who first detected the problem (internal/external)? } \\
\text { Problem was detected internally } \\
\text { To whom was the problem reported? } \\
\text { By the nail producer to the transporter, and then the } \\
\text { transportation company reported this issue to the } \\
\text { wire rod provider }\end{array}$ & $\begin{array}{l}\text { Who is not affected by the problem? } \\
\text { Transportation company } \\
\text { Who did not find the problem? } \\
\text { Transportation company }\end{array}$ \\
\hline 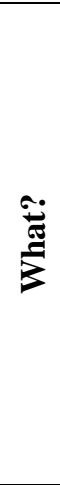 & $\begin{array}{l}\text { What type of problem is it? } \\
\text { Deep abrasions on some windings of several coils } \\
\text { What is affected by the problem? } \\
\text { Speed of processing of several coils with abrasions } \\
\text { What is happening? } \\
\text { Slowdown of manufacturing process } \\
\text { Do we have physical evidence of the problem in our } \\
\text { possession? } \\
\text { Photos taken by the nail producer }\end{array}$ & $\begin{array}{l}\text { What does not have the problem? } \\
\text { Quality parameters correspond to the } \\
\text { purchase order } \\
\text { What could be happening but is not? } \\
\text { Coils windings are not damaged and } \\
\text { accepted for processing } \\
\text { What could be the problem but is not? } \\
\text { Coils could be fully unacceptable for } \\
\text { processing }\end{array}$ \\
\hline$\ddot{\hat{z}}$ & $\begin{array}{l}\text { Why is this a problem? } \\
\text { Processing of some coils is not stable due to } \\
\text { breakage at the abraded places } \\
\text { Is the process where the problem occurred stable? } \\
\text { Loading, transportation, discharge could be } \\
\text { influenced by more severe control }\end{array}$ & $\begin{array}{l}\text { Why is it not a problem? } \\
\text { N/A }\end{array}$ \\
\hline 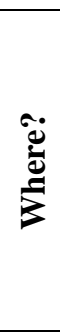 & $\begin{array}{l}\text { Where was the problem observed? } \\
\text { At the nail producer's storage yard } \\
\text { Where does the problem occur? } \\
\text { Suggested three options where the problem } \\
\text { occurred: at mill while loading, in transit, at the nail } \\
\text { producer yard, while discharging or in the } \\
\text { processing machines }\end{array}$ & $\begin{array}{l}\text { Where could the problem be located but } \\
\text { is not? } \\
\text { N/A } \\
\text { Where else could the problem be located } \\
\text { but is not? } \\
\text { N/A }\end{array}$ \\
\hline $\mathfrak{z}_{\tilde{z}}^{\ddot{z}}$ & $\begin{array}{l}\text { When was the problem first noticed? } \\
\text { After discharge at the nail producer's storage yard } \\
\text { When has it been noticed since? } \\
\text { When the nail producer started processing of coils }\end{array}$ & $\begin{array}{l}\text { When could the problem have been } \\
\text { noticed but was not? } \\
\text { N/A }\end{array}$ \\
\hline
\end{tabular}


Cont. table 2.

\begin{tabular}{|l|l|l|}
\hline & $\begin{array}{l}\text { Quantity of problem? } \\
\text { Several coils with abraded surfaces (based on the } \\
\text { photos sent by the client) }\end{array}$ & $\begin{array}{l}\text { How many individual items have the } \\
\text { problem but don't? } \\
\text { All coils could have serious damages }\end{array}$ \\
$\begin{array}{l}\text { How Much is the problem causing in EUR, people, } \\
\text { \& Time? } \\
\text { N/A }\end{array}$ & $\begin{array}{l}\text { How big could the problem be but is } \\
\text { Wire rods could not be processed or } \\
\text { processed with loss }\end{array}$ \\
\hline & $\begin{array}{l}\text { What is the trend (continuous, random, cyclical)? } \\
\text { Exclusively random }\end{array}$ & $\begin{array}{l}\text { What could the trend be but is not? } \\
\text { All deliveries could be affected, but were } \\
\text { not }\end{array}$ \\
\hline
\end{tabular}

Adapted from: Company materials.

In entering stage 3, the problem was narrowed down to that supposedly prime wire rod was loaded into trucks. When trucks arrived at the nail producer's yard, abrasion on the surface of several coils was found after discharge. Wire rod with such damages was processed with rather low efficiency due to breakage at abrasion sites. More human resources were involved in solving quality issues, more time was needed for processing, and as a consequence, more money was needed to cover the entire quality failure cost.

Interim containment actions were then applied. The temporary actions allowed constraint of the problem until permanent correction was in place. In accordance with D3 procedure, the temporary patch procedure regarding the problem was validated to ensure the situation was mitigated. Thus, all distributed coils were inspected and if possible, processed at suboptimal speed, to understand the scope of quality issue and to bring about a permanent solution by eliminating the problem from all future deliveries. The potential root causes were diagnosed.

During discipline $D 4$, team members identified and verified escape points. The team agreed that all three main places should be controlled carefully: the coil manufacturing process and uploading at the coil manufacturer, the truck in transit, discharging and processing at client plant.

By applying Ishikawa diagramming, the most likely causes of quality issues of the wire rod coils was made evident (Figure 3). To help to answer the question of what failed in the process, 5 Why? analysis was re-performed (Figure 4). 


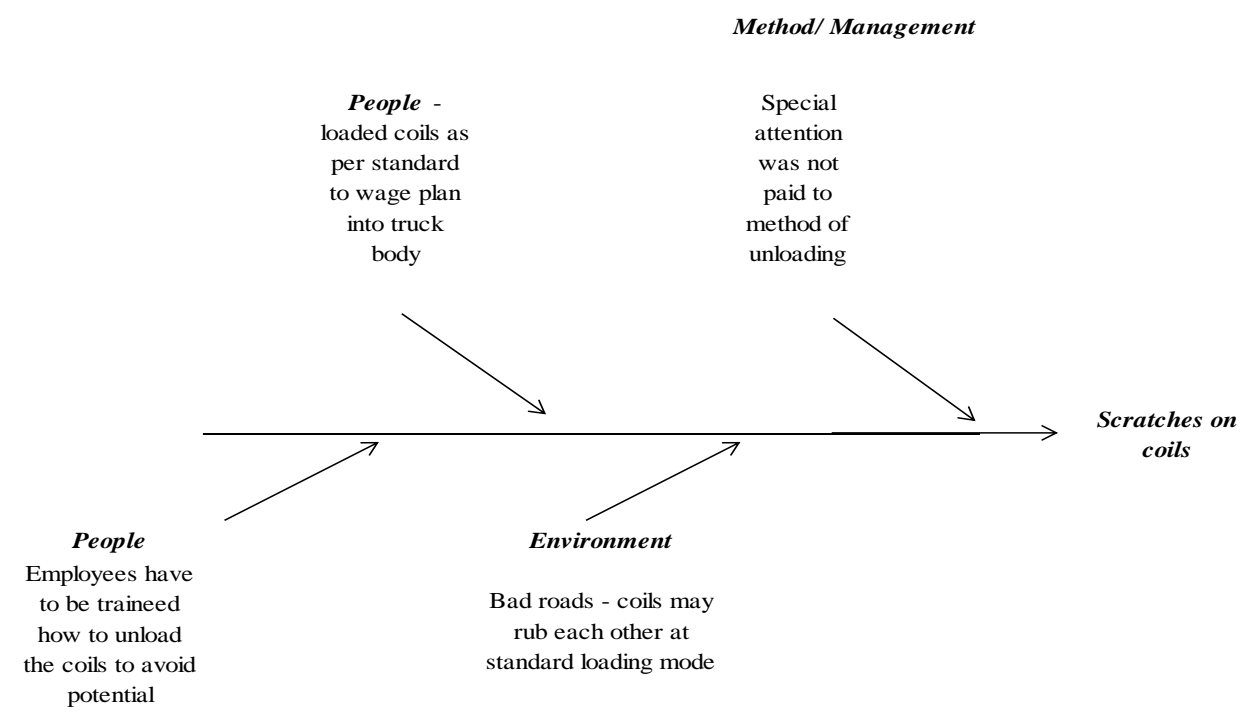

Figure 3. Ishikawa diagram of quality issues of the transported wire rod. Adapted from: Company materials.

\begin{tabular}{ll}
\hline $\begin{array}{l}\text { Why did this } \\
\text { happen? }\end{array}$ & parties did not agree to stowage mode in truck before loading \\
\cline { 2 - 2 } & bad road conditions \\
\hline coils rubbed each other \\
$\begin{array}{l}\text { drivers did not use additional fastening belts as needed } \\
\text { special spacers were not applied amid the each coil during the } \\
\text { transport process }\end{array}$ \\
\hline
\end{tabular}

Figure 4. The 5 Why? analysis to support Ishikawa diagramming. Adapted from: Company materials.

During the D5 phase, the possible solutions were identified and addressed to avoid subsequent failures. Solutions were determined to the best of all alternatives. It was agreed to document and verify the permanent corrective action (PCA). The corrective actions were listed below:

1. to use a specific stowage mode for loading (to keep an eye to the coil sides),

2. to have additional separation cardboards/ plastic spacers placed between coils,

3. to have additional fastening belts applied to the individual coil components,

4. to instruct drivers that they need to drive carefully at optimal speed,

5. to remind drivers to choose smooth roads and avoid holes in the road,

6. to ensure that the load is be discharged carefully by forklifts with rubber protectors on the forks,

7. to ensure dischargers be informed to not rub against coils during the manipulation process from the discharge place to the processing place,

8. to photograph each coil:
a) before loading,
b) on being loaded onto trucks,
c) before discharging, 
9. to prohibit the use of unprotected ropes (without protective rubber or plastic spacers) if discharged by crane.

During the D6 stage, the permanent corrective actions, listed in the D5 discipline, were implemented and then validated to ensure each affected individual knows what should be done. The team examined especially the loading and unloading process, stressing the need to check whether the carton/plastic spacers were put between each coil of wire rod and that a specific stowage mode was used for loading (shown on Figure 5 and Figure 6). The Team members did not detect any undesirable side effects in this mitigation effort. Return to root cause analysis was not performed because it was not necessary.

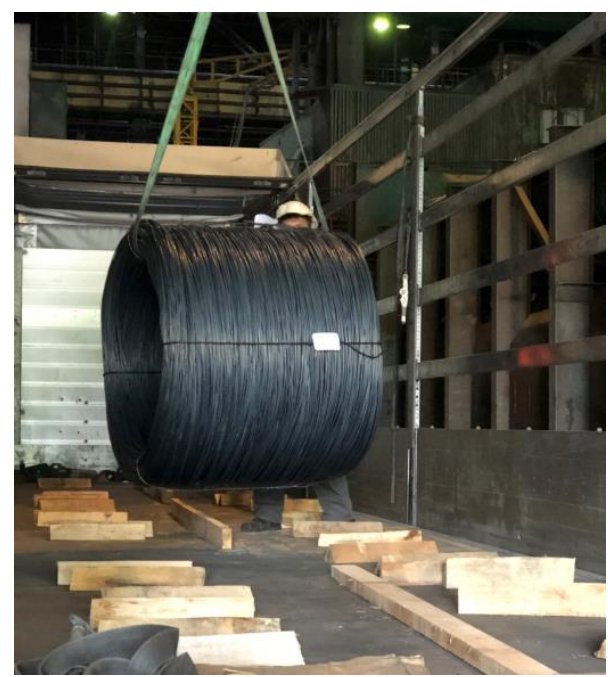

Figure 5. Specific stowage mode for loading. Adapted from: Company materials.

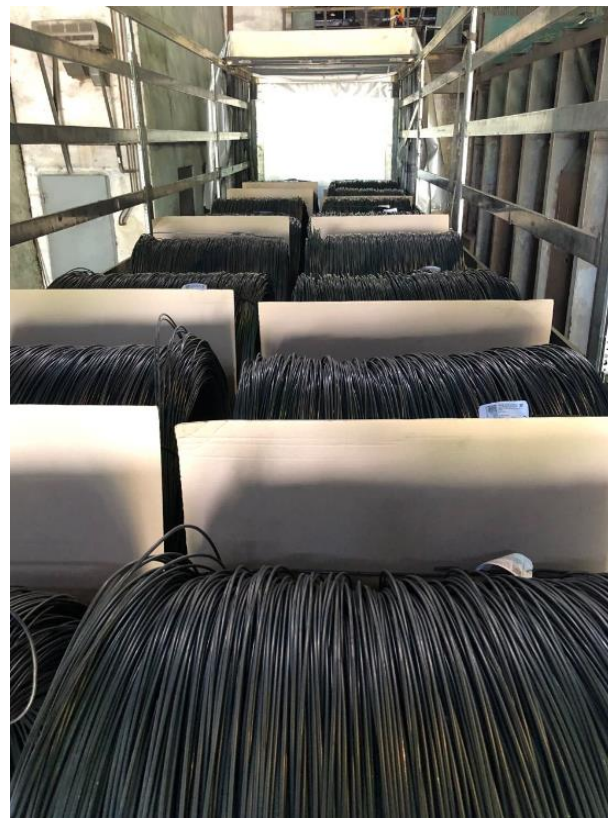

Figure 6. Carton boards among the wire rod coils, picture taken during the transport. Adapted from: Company materials. 
During $D 7$, the Team members did determine what improvements in systems and processes would prevent the problem from recurring. The crucial points turned out to be the loading, transportation and discharging processes, where many quality defects can happen without special load treatment. The entire team ensured that corrective action remained in place and was successful.

$D 8$ was the culmination of the entire team's efforts. The team leader thus congratulated the team. The G8D report was created and shown to interested parties from the nail manufacturer's side, as well as the transporter and wire rod coil provider.

\section{Conclusion}

The G8D method was applied in the case study of a wire rod coil quality issue. The research question for this investigation was: How to prevent quality issues of wire rod and to prevent their repeating? In the paper, a literature review allowed the reader to become acquainted with the frames of the G8D method and to see how it can be applied in a case study scenario. Therein, this structured method enabled the Team members to define the problem, identify and put in place a temporary fix and subsequently, to discover the full extent of the problem and then to put into place a permanent fix. During the research, supporting techniques/ tools (Ishikawa diagram, brainstorming, 5 Why? and 2 How? Analysis) were described and in the case study shown in actual use.

\section{References}

1. Babica, M., and Pająk, E. (2006). Koncepcja metody eliminacji niezgodności w procesach produkcyjnych. Zeszyty Naukowe Politechniki Poznańskiej. Budowa Maszyn i Zarządzanie Produkcja, 3, 5-15.

2. Banduka, N., Tadic, D., and Macuzic, I. (2018). Extended process failure mode and effect analysis (PFMEA) for the automotive industry: The FSQC-PFMEA. Advances In Production Engineering \& Management, 13, 206-215.

3. Chen, H., and Cheng, B. (2010). A case study in solving customer complaints based on the 8Ds method and Kano model. Journal of the Chinese Institute of Industrial Engineers, 27(5), 339-50.

4. Kumar, T.S.M., and Adaveesh, B. (2017). Application of "8D Methodology" for the Root Cause Analysis and Reduction of Valve Spring Rejection in a Valve Spring Manufacturing Company: A Case Study. Indian Journal of Science and Technology, 10(11), 1-11. 
5. Łuczak, J., and Maćkiewicz, E. (2006). 8D oraz inne metody zarządzania jakością w branży motoryzacyjnej (OE-OES) - analiza przypadku. Problemy Jakości, 11, 35-43.

6. Łuczak, J., and Matuszak-Flejszman, A. (2007). Metody i techniki zarządzania jakością. Kompendium wiedzy. Poznań: Quality Progress.

7. Pacana, A., and Czerwińska, K. (2017). Wykorzystanie metody 8D do rozwiązania problemu jakościowego. Zeszyty Naukowe Politechniki Częstochowskiej, 28, 73-86.

8. PN-EN ISO 9000:2015-10.

9. Ramachandran, T., Prakash, R., Karthik, R., and Kumar S. (2013). An application of G8D methodology as a problem solving tool in a manufacturing firm. International Conference of Sustainable Manufacturing and Operations Management ISOM. Conference Materials. Gyandhara, 331-335.

10. Rambaud, L. (2006). 8D Structured Problem Solving: A Guide to Creating High Quality 8D Reports. Breckenridge, USA: Phred Solutions.

11. Sarkar, S., and Rajagopalan, B. (2018). Consumer safety complaints and organizational learning: evidence from the automotive industry. International Journal of Quality and Reliability Management, 35, 10, 2094-2118.

12. Xu, Z., Dang, Y., Munro, P. (2018). Knowledge-driven intelligent quality problem-solving system in the automotive industry. Advanced Engineering Informatics, 38, 441-457. 